Fixed Point Theory, 18(2017), No. 2, 729-740

DOI 10.24193/fpt-ro.2017.2.59

http://www.math.ubbcluj.ro/ nodeacj/sfptcj.html

\title{
SATURATED FIBRE CONTRACTION PRINCIPLE
}

\author{
MARCEL-ADRIAN ŞERBAN \\ Department of Mathematics, Babeş-Bolyai University of Cluj-Napoca \\ M. Kogălniceanu Str., no. 1, 400048 Cluj-Napoca, Romania \\ E-mail: mserban@math.ubbcluj.ro
}

Abstract. For a triangular operator $A: X \times Y \rightarrow X \times Y, A=(B, C)$, where $B: X \rightarrow X$ and $C: X \times Y \rightarrow Y$ we study in which conditions on operators $B: X \rightarrow X$ and $C: X \times Y \rightarrow Y$ we have that:

(1) the fixed point problem for triangular operator $A=(B, C)$ is well posed

(2) the operator $A=(B, C)$ has the Ostrowski property

(3) the fixed point equation $(x, y)=A(x, y)$ is generalized Ulam-Hyers stable.

Key Words and Phrases: Cauchy lemma, fixed point, fibre contraction principle, well-posedness of the fixed point problem, Ostrowski property, Ulam-Hyers stability, generalized Ulam-Hyers stability.

2010 Mathematics Subject Classification: 47H10, 54H25, 65J15, 34A34, 34A12, 45G10.

\section{REFERENCES}

[1] S. Andrász, Fibre $\varphi$-contraction on generalized metric spaces and applications, Mathematica (Cluj), 45(68)(2003), no. 1, 3-8.

[2] C. Bacoţiu, Fibre Picard operators on generalized metric spaces, Sem. on Fixed Point Theory Cluj-Napoca, 1(2000), 5-8.

[3] M.F. Barnsley, V. Ervin, D. Hardin, J. Lancaster, Solution of an inverse problem for fractals and other sets, Proc. Nat. Acad. Sci. USA, 83(1986), 1975-1976.

[4] V. Berinde, Error estimates in the $\varphi$-contractions, Stud. Univ. Babeş-Bolyai Math., 35(1990), no. $2,86-89$

[5] V. Berinde, M. Păcurar, I.A. Rus, From a Dieudonné theorem concerning the Cauchy problem to an open problem in the theory of weakly Picard operators, Carpathian J. Math., 30(2014), no. 3, 283-292.

[6] V. Berinde, A. Petruşel, I.A. Rus, M.A. Şerban, The retraction-displacement condition in the theory of fixed point equation with a convergent iterative algorithm, In: T. M. Rassias and V. Gupta (eds.), Mathematical Analysis, Approximation Theory and their Applications, Springer Optimization and Its Applications, 111(2016), 75-106.

[7] L.M. Blumenthal, Theory and Applications of Distance Geometry, Oxford University Press, 1953.

[8] A. Boucherif, R. Precup, On the nonlocal initial value problem for the first order differential equation, Fixed Point Theory, 4(2003), no. 2, 205-212.

[9] A. Chiş-Novac, R. Precup, I.A. Rus, Data dependence of fixed points for nonself generalized contractions, Fixed Point Theory, 10(2009), 73-87.

[10] M. Fréchet, Les espaces abstraits, Gauthier-Villars, Paris, 1928. 
[11] V. Glăvan, V. Guţu, Shadowing in parametrized IFS, Fixed Point Theory, 7(2006), no. 2, 263274.

[12] J. Jachymski, An extension of Ostrowski's theorem on the round-off stability of iterations, Aequa. Math., 53(1997), no. 3, 242-253.

[13] O. Nica, R. Precup, On the nonlocal initial value problem for first order differential systems, Stud. Univ. Babeş-Bolyai Math., 56(2011), no. 3, 113-125.

[14] J.M. Ortega, W.C. Rheinboldt, Iterative Solutions of Nonlinear Equation in Several Variables, Academic Press, New York, 1970.

[15] A. Petrussel, I.A. Rus, An abstract point of view on iterative approximation schemes of fixed points for multivalued operators, J. Nonlinear Sci. Appl., 6(2013), no. 2, 97-107.

[16] S. Yu. Pilyugin, Shadowing in Dynamical Systems, Springer, Berlin, 1999.

[17] I.A. Rus, A fibre generalized contraction theorem and applications, Mathematica (Cluj), 41(1999), no. 1, 85-90.

[18] I.A. Rus, An abstract point of view on iterative approximation of fixed point equations, Fixed Point Theory, 13(2012), no. 1, 179-192.

[19] I.A. Rus, Fibre Picard operators and applications, Stud. Univ. Babeş-Bolyai Math., 44(1999), 89-98.

[20] I.A. Rus, Fibre Picard operators on generalized metric spaces and applications, Scripta Sci. Math., 1(1999), 326-334.

[21] I.A. Rus, Generalized Contractions and Applications, Cluj University Press, Cluj-Napoca, 2001.

[22] I.A. Rus, Metric space with fixed point property with respect to contractions, Stud. Univ. BabeşBolyai Math., 51(2006), no. 3, 115-121.

[23] I.A. Rus, Picard operators and applications, Sci. Math. Jpn., 58(2003), 191-219.

[24] I.A. Rus, Picard operators and well-posedness of fixed point problems, Stud. Univ. Babeş-Bolyai Math., 52(2007), no. 3, 147-150.

[25] I.A. Rus, Relevant classes of weakly Picard operators, An. Univ. Vest Timiş. Ser. Mat.-Inform., 54(2016), no. 3, 3-19.

[26] I.A. Rus, Results and problems in Ulam stability of operatorial equations and inclusions, In: T.M. Rassias (ed.), Handbook of Functional Equations. Stability Theory, Springer, 2014, 323352.

[27] I.A. Rus, Some variants of contraction principle, generalizations and applications, Stud. Univ. Babeş-Bolyai Math., 61(2016), no. 3, 343-358.

[28] I.A. Rus, The generalized retraction methods in fixed point theory for nonself operators, Fixed Point Theory, 15(2014), 559-578.

[29] I.A. Rus, Weakly Picard operators and applications, Seminar on Fixed Point Theory, ClujNapoca, 2(2001), 41-58.

[30] I.A. Rus, A. Petruşel, G. Petruşel, Fixed Point Theory, Cluj University Press, 2008.

[31] I.A. Rus, M.A. SSerban, Basic problems of the metric fixed point theory and the relevance of a metric fixed point theorem, Carpathian J. Math., 29(2013), no. 2, 239-258.

[32] I.A. Rus, M.A. Serban, Some generalizations of a Cauchy Lemma and Applications, Topics in Mathematics, Computer Science and Philosophy (Şt. Cobzaş-Ed.), Cluj University Press, 2008, 173-181.

[33] J. Sotomayor, Smooth dependence of solutions of differential equations on initial data: a simple proof, Bol. Soc. Bras. Mat., 4(1973), 55-59.

[34] M.A. Şerban, Fibre contraction theorem in generalized metric spaces, Automat. Comput. Appl. Math., 16(2007), no. 1, 139-144.

[35] M.A. Şerban, Fibre $\varphi$-contractions, Studia Univ. Babeş-Bolyai Math., 44(1999), no. 3, 99-108.

[36] M.A. Şerban, Fixed Point Theory for Operators on Cartesian Product (in Romanian), Cluj University Press, Cluj-Napoca, 2002.

Received: December 8, 2015; Accepted: November 10, 2016. 
